\title{
Adapting Hunter S. Thompson's Writing to Cinema: Despicable Characters and (apparent) Lack of Purpose
}

\author{
Manuel João de Carvalho Coutinho \\ ICNova - FCSH, Portugal
}

\begin{abstract}
Back in October 30, 1974 the eyes of the world were set upon what has been called by some as the greatest sporting event of the 20th century. In the capital city Kinshasa, in the Democratic Republic of the Congo (then called Zaire), the historic boxing event took place pitting the undefeated world heavyweight champion George Foreman against the challenger Muhammad Ali, the former heavyweight. Many reporters from around the world were present, resulting in great works such as journalist Norman Mailer's The Fight (1975). To cover the momentous event, Rolling Stone magazine sent a reluctant Hunter S. Thompson, who ended up scalping the fight tickets and instead spent the historic moment alone in his hotel's pool indulging in drugs and a bottle of Chivas Regal whiskey.

To analyse Hunter S. Thompson's work is to confront oneself with the rambles of a mad man making up rules as he goes through life. From his numerous books, two have been adapted to feature films: Fear and Loathing in Las Vegas (1998) and The Rum Diary (2011). By mainly deconstructing the latter movie through the ideology of Thompson and its Gonzo journalism with its drug-infused aesthetics and personal experience reporting, I will explore the often misunderstanding of Thompson's characters and the (apparent) lack of purpose that appears to motivate them. In order to present this argument, this study will consider different characters and moments from the original book The Rum Diary and analyse how/why they were changed in the final movie.
\end{abstract}

Keywords: Gonzo, Journalism, Cinema, Art, Motivation

\section{Introduction}

When watching Fear and Loathing in Las Vegas (1998), it is easy to feel that the chaotic drug and alcohol infused movie seems to have no apparent meaning besides the spectacle and surrealistic scenes that follow the depraved and unscrupulous main character. The reptile murderous orgy in the casino and the dialogue concerning Lucy in the hallway of the hotel room are two of the most troubling examples that easily come to mind. If you ask anyone for a similar movie to watch or go online and read through different listicle websites and movie aggregators, most suggestions will point you to other works from the main actor Johnny Depp (like Sleepy Hollow 1999, or Blow 2001) or the director Terry Gilliam (Brazil 1985, or The Imaginarium of Doctor Parnasssus 2009). If you go by themes, some will suggest movies related to a sense of freedom and on the road experiences (Easy Rider
1969; Almost Famous 2000), others will go the other way and relate the movie with a murderous feeling of paranoia (Fight Club 1999; American Psycho, 2000). But most suggestions will eventually point you towards movies with self-indulgent alcoholism, from comedy (Hangover, 2009) to self-destruction (Leaving Las Vegas 1995); or even darker and more destructive drug related experiences (Trainspotting 1996; Requiem for a Dream 2000). And of course, among all these suggestions there is always and ultimately the movie The Rum Diary (2011).

Only two books written by journalist Hunter $S$. Thompson have been adapted to movie form (Fear and Loathing in Las Vegas 1998, and The Rum Diary 2011) with others loosely depicting the author's stories (Where the Buffalo Roam 1980) and a number of documentaries profiling his persona (Breakfast with Hunter 2003; Buy the Ticket, Take the Ride: Hunter S. Thompson on Film 2006; to name a few). Hunter $\mathrm{S}$. Thompson rose to fame first with his book Hell's Angels (1967) where he spent a year living and riding with the motorcycle club Hell's Angels. Four years later, he cemented his place in literature with the book Fear and Loathing in Las Vegas (1971). By 1975, as Alex Gilbey argues in the documentary Gonzo (2008), “(...) Thompson's best work was done (...)." (McNair 2010, 131) And yet, decades later Thompson's irreverent style continues to be admired and still inspires journalists worldwide (see 2018's book Fear and Loathing Worldwide: Gonzo Journalism Beyond Hunter S. Thompson). As Doug Underwood explains, Thompson is part of the revolutionary literary movement of the:

(...) period of the 1960 s and 1970 s when the so called «new journalism» movement appeared on the scene as a reaction to the "daily-ness» of mainstream journalism and the increasingly esoteric trends in contemporary fiction-writing and academic literary criticism. (Underwood 2008, 31)

Indeed, Hunter is often associated with the new journalism movement cemented with the 1975 book by Tom Wolfe (New Journalism) where Hunter features alongside journalists Truman Capote, Gay Talese and Norman Mailer. This was an era, as Underwood explains, of:

(...) rich literary experimentation. This era saw the rise to celebrity of a group of ex-journalists who have been identified as "beat" or "rebel writers", including [Hunter S.] Thompson, Jack Kerouac, Henry Miller, Charles Bukowski (...). It was also the period (...) that would allow journalists to express themselves in highly personalized, stylized and textured forms of writing that broke from conventional journalistic traditions (...). (Underwood 2008, 18) 
While Thompson is correctly associated with these and other literary movements of the 1960s and 70s, he is also the father of a subgenre called "gonzo journalism" which "(...) began after he wrote his first book, The Hell's Angels." (Wolfe 1975, 195) The origins of the word gonzo seem to be muddled, although there are some that relate " $(\ldots)$ its roots in Boston bar culture, and referring to the last man standing after a heavy drinking session (...)." (McNair 2010, 129) At this point one could easily be confused and wonder about the importance of understanding the differences between new journalism, or a subgenre such as gonzo or any other term to truly grasp the movie adaption's of Hunter's work. Indeed, this confusion is reasonable and other essays are more preoccupied at defining these literary/journalistic academic differences. The important aspect to focus on is that this type of journalistic work that defined new journalism stands out, for the most part, on the principle of being a journalistic endeavor and thus it is portrayed as a factual narrative. Gonzo journalism, however, was a different type of journalism, one:

(...) which took the literary elements of the New Journalism (...) and then added something else - not mere authorial presence at the scene of the events being reported (...) but provocation by the reporter of those being observed and reported on. The consequences of this participation-provocation would then be described in prose heavily influenced by alcohol and other drugs, undermining the reliability of the narrator but heightening the descriptive power of the prose and the force of its author's message. (McNair 2010, 129)

Focusing heavily on this aspect of personal experience, hard hitting opinions and boisterous excess; Hunter's narratives stand out due to the constant presence of the author and its expressive, and at times graphic, real-life stories. As Mcnair explains:

In his foreword to The Proud Highway William J. Kennedy describes Thompson as "a journalistic fictionist (...). Thompson created himself as a character in his own writing, and it was never entirely clear if this character was real or imagined. In claiming to be a journalist, however, Thompson also laid claim to the privileged cultural status of factuality." (McNair 2010, 130)

And while this strange persona is evident and justly depicted in the movie adaption of the book of the same title Fear and Loathing in Las Vegas, the same could not be said about the movie The Rum Diary. And in there lies, as I hope to explain, the issue with this adaption.

\section{Hunter S. Thompson: the writer and journalist and the origins of the book The Rum Diary (1998)}

For context purposes, it is important to address the backstory of the book The Rum Diary published in 1998 and its subsequent movie with the same title released in 2011. Going all the way back to Hunter S. Thompson's youth, it is important to note that back then he was already a remarkable writer, so much so that he " $(.$.$) impressed his English teacher (...)" who$ recommended him to the "(...) Athenaeum Literary Association (...) whose members contributed pieces to the association's annual yearbook, The Spectator." (Weingarten 2006, 125). In one of his Spectator essays, teenager Thompson laid out his contempt for a life of safety and dullness, by stating:

Turn back the pages of history and see the men who have shaped the destiny of the world. Security was never theirs, but they lived rather than existed (...). It is from the bystanders (who are in the vast majority) that we receive the propaganda that life is not worth living (...) that the ambitions of youth must be laid aside for a life which is but a painful wait for death. (Weingarten 2006, 126)

Despite Thompson's promising talent, however, in 1956 right before his graduation he is charged and sentenced to 60 days in jail for being an accessory to a robbery after being in a car with the culprit. Hunter serves 31 days and while in jail, his school's superintendent refuses his request to take his high-school final examinations and thus he is unable to graduate. A week after being released from prison, he enlists in the United States Air Force.

At the Air Force, he successfully completes basic training and experiences his first professional writing job as a sports editor at The Command Courier. After a number of travels, while writing the sports column for The Playground News, Hunter is honorably discharged as an airman first class in 1957, with W.S. Evans, his Chief Office of Information noting in his report:

\begin{abstract}
Airman Thompson possesses outstanding talent in writing. However (...) Airman Thompson has consistently written controversial material (...). This Airman has indicated poor judgment from other standpoints (...). In Summary, this Airman, although talented, will not be guided by policy or personal advice and guidance. Sometimes his rebel and superior attitude seems to rub off on other airmen staff members. (Thompson 2009, 13)
\end{abstract}

From 1957 to 1959 , Hunter moves from one job to another with some personal success to his name first by publishing his first story and later through landing a job in the renowned publication Time. But even that is short lived and Thompson is fired after only one year. During this time he started writing his first novel called King Jellyfish (still to be published) and he submits several short stories to various magazines with little success. In 1959 he takes up:

(...) a job in Puerto Rico on El Sportivo, a weekly sports magazine that emphasized bowling coverage, and he freelanced for the Louisville Courier-Journal on the side. El Sportivo went out of business shortly thereafter. Thompson decamped to Big Sur, on the northern California coast, in order to start working on another novel based on his Puerto Rico adventures, to be called The Rum Diary. (Weingarten 2006, 129) 
By 1964, after working in a number of different places this novel is still unfinished despite Hunter's best efforts. When in December of that year Carey McWilliams, the editor of the weekly The Nation inquires Hunter on the possibility of writing about the outlaws called Hell's Angels, the effort to finish his novel is put on "hold" indefinitely and his career takes off (Weingarten 2009, 131).

More than three decades later, around 1997, actor Johnny Depp was spending time with Hunter S. Thompson and getting acquainted with his quirks and personality to play him in the movie Fear and Loathing in Las Vegas (1998). Suddenly, while in Thompson's house, he stumbled on a cardboard box and in it was The Rum Diary, still unfinished. ${ }^{1}$ With the success of the movie Fear and Loathing in Las Vegas and the renewed interest in Thompson's work, he was convinced and interested in publishing The Rum Diary, even though he started writing it almost forty years before and he no longer related with many parts of it. To bring the book to life, Hunter S. Thompson worked with a number of editors and friends with whom he often clashed due to his input and perspective concerning changes to his novel. As journalist Curtis Robinson points out, in the process of editing, Thompson:

(...) would want to start to tweak it [the book], and the problem with Hunter was that anything he touched suddenly became a mature Hunter S. Thompson thing, because his style was so evident. (...) It was amusing in a way but it could be a horrible thing to watch. ${ }^{2}$

In one such moment captured in video, Marysue Rucci, editor of the American publishing company Simon \& Schuster, is reading one passage from The Rum Diary and Thompson finds that particular extract to be tacky and juvenile. He states "I don't know about that". Marysue quickly replies that she loves that passage implying that it should be left in the final book. Thompson accepts it stating: "Ok." He continued: "Well, at twenty-two you can write $s^{* * *}$ like that." This interesting moment thus reinforces Thompson's clear distance from this book that he started writing decades back.

In 1998, the same year that Fear and Loathing in Las Vegas premiers in cinemas, The Rum Diary is finally published and Hunter starts promoting it. In one of the interviews at the time concerning the novel, he was asked about his own interest in publishing such a long-lost novel now. Hunter states that he would have published in the sixties when he originally wrote it but the book at the time" (...) bounced about seven times - I got the standard list of rejection letters $(\ldots)$ " and he got involved in other things, stating that "(...) I came back from South America and I got into the politics of the $60 \mathrm{~s}$ and $70 \mathrm{~s}$, and it was a full time job." ${ }^{\prime 4}$ And to justify why the book should be published now, Thompson responds in his characteristic upfront attitude and bluntness by stating, in his rumbling way of talking, that he revisited the book because:
(...) it's got a romantic notion. That and money. (...) I was faced with the fact of having to dig out my 40-year-old story. I can't change it, like, "ye gods, this is me, this is the world I lived in". So I approached it as a writer. It's a good story. ${ }^{5}$

For the next couple of years, both Johnny Depp and Thompson, at that time already good friends, tried to make the book into a movie by having regular meetings in Depp's backyard with several producers. This effort would prove useless as the process dragged on without success. Thompson got so fed up with the whole process that he famously wrote a letter to a movie executive that, in itself, is a great piece of writing. ${ }^{6}$ Thompson would never see the movie made since in February 2005, after years of alcohol and cocaine abuse that contributed to his depression; he took his life with a shotgun. In March 2009, after Depp's continuous insistence in proceeding with this project, eventually the film finally moves forward with principal photography beginning in Puerto Rico. Two years later, the movie is released in cinemas.

\section{Understanding and deconstructing The Rum Diary: The 1998 book and the 2011 movie}

When comparing a movie adaptation to its original source material, in this case a book, it is easy to use tired old expressions like "the book is better" or "the movie does not do the book justice". From the start, let me reiterate that there is no sense in using these expressions or others here since, for all intents and purposes, any process of adaption always brings multiple different sides into the equation. And a movie, for that matter, brings in the writers that are adapting it, the director, the producers, the actors, the time and place used to adapt said work; among many other different elements that affect the final result. At the same time, if one sees a movie that adapts a book, and one is knowledgeable about the book, then we are also adding in another element into the equation: that is, our own opinions and experiences of said adaption, plus how our conceptions and misconceptions concerning the original source material. Since any process of experiencing something implies the users' individuality and personal taste, it is impossible to recreate or explain said experience to someone else, even if the tools and source material are the same. So, with that in mind, let us focus on the idea that motivated the movie and why it defines its adaption, making it - as I will argue - a misunderstanding of Gonzo and the whole journalistic subgenre that defined Hunter S. Thompson's career and ultimately his life.

The Rum Diary, both the book and the movie, in simple terms, tells the story of an American reporter, Paul Kemp, who travels to Puerto Rico to work at a local newspaper (just like the author Hunter S. Thompson did in 1959). In his experiences in Puerto Rico, he meets a number of other journalists who, like him, feel lost in a foreign country. In his adventures, he is struck by a blonde American named Chenault and eventually "clashes" with her boyfriend. Here is where 
things take a turn. In the book Chenault's boyfriend is Yeamon, a ruthless and cocky individual whose aggression is often directed towards his lover. Kemp is exasperated by the way Yeamon treats Chenault and this divides their initial friendship. To further consider the argument presented in this essay concerning the misunderstanding of Gonzo and Hunter's book, this study will consider two main crucial moments that serve the story as a whole. One takes place when the main character Paul Kemp meets Yeamon for the first time and he remarks that Yeamon:

(...) was familiar (...) but not quite (...) more like a memory of somebody l'd known in some other place and then lost track of. He was probably twenty-four or -five and he reminded me vaguely of myself at that age - not exactly the way I was, but the way I might have seen myself if l'd stopped to think about it. Listening to him, I realized how long it had been since l'd felt like I had the world by the balls (...). (Thompson 1998, 24)

The second moment to take notice takes place right before Chenault and Kemp talk for the first, when Kemp is going to Yeamon's beach house and notices something near the reefs. Now, at this point Yeamon and Kemp are friendly, and while the latter has not spoken to Chenault, he has seen her before when he came to the island on a plane and already then he was infatuated by her. And so the following scene takes place when he arrives at the beach house and, after finding it empty, he looks for them:

I crossed the patio and walked out (...) to the beach. (...) Then I saw two figures clinging together near the reef. I recognized Yeamon and the girl (...). They were naked, standing in waist-deep water, with her legs locked around his hips and her arms around his neck. Her head was thrown back and her hair trailed out behind her, floating on the water like a blonde mane. At first I thought I was having a vision. The scene was so idyllic that my mind refused to accept it. I just stood there and watched. (...) Then I heard a sound, a soft happy cry as she stretched out her arms like wings. I left then, and drove back (...). I bought a small bottle of beer for fifteen cents and sat on a bench in the clearing, feeling like an old man. The scene I had just witnessed brought back a lot of memories - not of things I had done but of things I failed to do, wasted hours and frustrated moments and opportunities forever lost because time had eaten so much of my life and I would never get it back. I envied Yeamon and felt sorry for myself at the same time, because I had seen him in a moment that made all my happiness seem dull. (Hunter 1998, 38)

It is important to note, at this point, that Yeamon is Kemp's co-worker and they both started at the same time working in the newspaper. As the story progresses, we see how Kemp is a better writer than Yeamon. At one moment Kemp is even asked to try and edit one of Yeamon's articles into something usable, and he notes how the article's writing is "pretty dull" (Hunter 1998, 60). Yeamon is eventually fired from the newspaper and as time passes (and his finances and aspirations dwindle) he becomes more and more bitter and violent as he directs his hatred towards Chenault. Yeamon also swears vengeance on the newspaper's editor, seeing him as one of the main reasons for his shortcomings and failure to succeed. Now, if we search for the subtext and seek to interpret this book by connecting it to its author's real life experiences (and our own projections), we could argue the possibility that Hunter S. Thompson is both Kemp and Yeamon, two sides of the same individual. Since Thompson's books are always somewhat personal and this one comes from his experiences in Puerto Rico it is easy to think that he is Kemp, a good writer who seems to be lost as he jumps into a new job and uses his talents in a forsaken publication always on the brink of folding while spending most of the time drinking; and the other is Yeamon who blames everything and everyone for his failures while having a loving partner that he is unable to appreciate and that he eventually loses. This book being a work of fiction, any similarities are in theory just that but Hunter's closeness and likeness to both individuals he created is still there.

This subtext was not lost in the editing process of the book back in 1998 when he is asked by one of those helping him: "What happened to the real Chenault?". Hunter ponders for a second and then laughs. Since he does not offer an answer, he is further inquired on her whereabouts until someone offers the following possibility: "[Chenault] is Sandy [Sandra Conklin, Hunter's ex-wife] and you married her!?". He replies: "Well, nobody is anybody here." $\mathrm{He}$ is met with laughter by those in the room and says nothing more of Chenault or the reality of the novel. Although later that year in an interview he is asked about both the characters of Yeamon and Kemp, and the interviewer asks point blank if he is the latter. He replies: "No (...) I was very careful not to make any one character me." The interviewer insists and Thompson relents:

I tried to split myself up (...) I was really both of those characters and uh the whole thing it's very real. I am not sure where I find myself sometimes in Yeamon, sometimes in Kemp. ${ }^{8}$

It might seem at first sight that Hunter's answer is him folding, him giving up the plan all along, while months prior in the editing room he denied his likeness to any character. Either that or he recognizes the dichotomy between Yeamon and Kemp as a clear representation of him and a somewhat self-evident truth of the book and thus sees no reason to hide it. Concerning Chenault, however, he holds his cards close to him and does not offer any semblance of truth. The fact that the book was published almost forty years after he started writing it also adds to the mystic of it all: the hopeful protagonist of the book as a better side of him not yet disappointed and harsh about life and Yeamon as his more aggressive side, someone that he relates in the book the first time he appears as someone "(...) familiar (...) more like a memory of somebody l'd known in some other place (...)." (Thompson 1998, 24) 


\section{Concerning adaptation and the problem of inserting Gonzo in everything of Hunter S. Thompson}

The movie's adaption of The Rum Diary, however, throws away any such context discussed previously. For starters, the character of Yeamon is nowhere to be seen. Chenault is present but her lover in the movie is not Yeamon - of course, because he is not there - in his place is the character of Sanderson, a vile and rich individual who seeks to make a fortune with Puerto Rico's natural beauty. Sanderson also appears in the book, but as a minor character with very little importance. By making Yeamon disappear in the movie, we are left with Kemp, a character that the movie adapts as a Hunter S. Thompson surrogate, seeking drugs and alcohol aimlessly and with an inserted subplot of saving journalism. By writing Sanderson as a bigger character in the movie, he serves as the antagonist, with no redeeming quality which makes it hard to understand why Chenault is following in his side despite his clear rudeness. And so the moment that the character of Kemp first meets Chenault, a moment we previously quoted, is not such a powerful moment as it is in the book because Kemp is not close to Sanderson in any way, there is no semblance or feeling of admiration despite his limitations (as in Yeamon). Kemp in the book already knows Yeamon at that point and when he is invited to his beach house, he arrives early and notes how their beach house looks like a cell. And then he sees Chenault and Yeamon by the reefs and he resents him, wishing to be him. He finds himself again drinking as he ponders on his life and lack of happiness. He is a good writer but he does not have her, he is not Yeamon even due he is kinder and more talented than him. While adapting this moment to the movie, things are so different that this powerful moment loses all meaning. Kemp has met Chenault at that point and is invited by Sanderson, who is hiring him, to visit his place where he sees them enthralled in one another in the water. But Sanderson's place is not a cheap beach house that looks like a cell; instead it is a mansion with a private beach. And when they are making love in the water they are not against uncomfortable reefs, instead they are next to Sanderson's big and expensive sailboat. Kemp does not ponder on the meaning of happiness as he watches them through a telescope, instead he is surprised and lustful as he audibly groans, but he is not shocked or resentful and thoughtful about his own life choices. Money bought all of that, it even bought the company of Chenault until the moment Sanderson leaves her.

The problem with adapting the book this way is that the movie fails to understand that The Rum Diary is not Fear and Loathing in Las Vegas, and there is a need to separate both instead of trying to make one more like the other. As Brian McNair points out:
The success of the first book, [Fear and Loathing in Las Vegas] and then the film of the book (...) signal our readiness to see the world not through the eyes of the objective reporter alone (and gonzo never replaced conventional journalism, merely challenged its self-proclaimed monopoly on truth) but also through the eyes of the artist in journalist's clothing. Through the unique perspective of the aesthetically gifted, sensitive individual, we approach the truth which the best and most diligent of BBC News or CNN reporters may miss. (McNair 2010, 131)

The Rum Diary is different from other works from Hunter S. Thompson because he is not in the original book since it is not about the author's experiences while reporting and/or experiencing an event. It is fiction and gonzo journalism is absent from it because, for all intents and purposes, it is not Gonzo.

To further explore this, let us consider again Tom Wolfe's New Journalism (1975), the book that praised this new genre as a challenge to what was perceived to be the dull journalism from its time. In this book, Thompson is featured twice, first with an extract from his 1970 article The Kentucky derby is decadent and depraved, and secondly from his 1967 book Hell's Angels. Both times his work is accompanied by a short introduction written by Tom Wolfe where he offers some insight on the author and the work at hand. Concerning the 1970 article, Wolfe states that Hunter's style is:

(...) a manic, highly adrenal first-person style in which Thompson's own emotions continually dominate the story. This approach seldom grates in Thompsons's hands, probably because Thompson, for all his surface ferocity, usually casts himself as a frantic loser, inept and half-psychotic (...). (Wolfe 1975, 195)

And indeed Thompson's characters are not the most ethical or admirable of individuals, usually being self-centered agitators who prefer the company of a bottle or hard drugs. In the same book, this time introducing the extract from Thompson's 1967 book, Tom Wolfe however points out to a different narrative style stating that:

Thompson's use of the first person (...) is quite different from the way he uses the first person later in his Gonzo Journalism. Here he uses himself solely to bring out the character of the Angels and the locals. (Wolfe 1975, 373)

If one could argue that a writer creates his own style the more he perfects it, sometimes running the risk of being defined and labeled by it, then it is evident through both introductions by Wolfe that Hunter S. Thompson's 1967 book does not yet have his signature mark - Gonzo - while the 1970 book is closer to it. This is why it is not unreasonable to argue that The Rum Diary, the book that he started to write in 1959 , is far from this later style that he adopted further on and therefore should not be confused or inserted in the adaption of the novel, as it is in many aspects of the 2011 movie. We could even argue that Thompson's Gonzo style would perhaps never developed if he had found success with his early fiction, The Rum Diary 
included, as seem to indicate his early letters collected in book form:

The first volume of his letters, The Proud Highway (1997), makes it clear that from an early age his ambitions were novelistic rather than journalistic, and that his model, or hero, was Ernest Hemingway, another journalists who saw fiction as the more worthy form. Where Hemingway successfully made the leap from reporter to novelist, however, Thompson by his own account stumbled on another path to literary greatness, defining his own journalistic sub-genre gonzo. (McNair 2010, 129)

\section{Conclusion: "Some may never live, but the crazy never die" - Hunter S. Thompson}

With that in mind, and again returning to The Rum Diary as I conclude this essay, I argue that the character of Kemp is Hunter's writer side, prolific and yet unstable while he moves from one publication to another somewhat without purpose and envying the life of others and the beauty he is denied in Chenault. Yeamon is his aggressive side, lashing out on newspapers editors and sabotaging himself and the one who loves him in the process, something that the real Hunter S. Thompson did time and time again. Chenault is the company he wishes he had, beautiful but wild and troubled like him. And she chooses Kemp after losing control of herself since he is better that Yeamon: he is flawed, yes, but talented and a bon-vivant that has better self-control, despite everything, and less self-hate and self-sabotage. Chenault needs to find herself in the end of the book and so she leaves Kemp but asks him to meet him in New York. In the movie, since there is no duality in Kemp-Yeamon, there is little to no weight to Kemp's sudden decision to defend journalism, a subplot the movie creates and recognizes its frailty when his newspaper boss in the movie states:

"It's called journalism!" [says Kemp, with his boss replying] "Oh, make me laugh! I asked you to tidy up the booze, you couldn't even sweep out a room. Why do you think you're working here? 'Cause you're everything that's wrong with a journalist."

(The Rum Diary 2011)

In the movie, Chenault is also with him at the end before leaving but without ever asking Kemp to come meet her in New York. Still, and perhaps seeking that "happy ever after" ending the movie concludes with a somewhat unsatisfying epilogue text on screen stating that Kemp married Chenault and became one of the best and most revered American journalists, and that he found his voice by seeking justice and fighting against the bastards of the world.

By adapting the book this way, I here argue that the movie is something else, entertaining but different from the book entirely. That is not so bad, if that was what was needed to see it through as a motion picture. At the same time, it is an example of how interpretation takes a big role when adapting someone's early work whilst enamored by his or her later work, and how that can define your vision as a director and screenplay writer which, in the particular example of The Rum Diary, happens to be the same individual. At the end of the day, the movie The Rum Diary is a love letter to Thompson, one that sees the character that represents the author - Kemp - as being more controlled of himself, able to live a happy life with the woman he loves and with a sense of purpose and success while still receiving the respect by his community of journalists, a respect that eluded the real Hunter S. Thompson so many times in life due to his tenuous distinction between fact and fiction.

According to actor Johnny Depp, each day in the set of The Rum Diary there was a chair with Hunter's name on it, along with the movie's script, an ashtray, cigarettes and an empty glass with a bottle of Chivas Regal whisky next to it. In his words, it was a way "(...) to recognize Hunter, to salute him." And while the movie misses the mark in capturing the deeper meaning of the book, it does a good job in recognizing Hunter S. Thompson's persona and, in my opinion, any opportunity to salute him is worth it.

\section{Final Notes}

${ }^{1}$ Martin, Daniel. “Johnny Depp remembers unearthing 'The Rum Diary' - video.” NME. Publication date November 10, 2011, https://www.nme.com/news/film/johnny-depp-remembersunearthing-the-rum-diary-vid-878610.

2 "Hunter S. Thompson: Back Story of The Rum Diary", YouTube video, 45:54, "ritziszen," March 29, 2015, https://www. youtube.com/watch?v=Ny9-ENnOIFk\&ab channel=ritziszen.

3 "Hunter S. Thompson: Back Story of The Rum Diary".

4 "Hunter S. Thompson interview on "The Rum Diary" (1998)", YouTube video, 22:52, "Manufacturing Intellect," July 28, 2016, https://www.youtube.com/watch?v=LKJbua_ItOo\&ab_channel= Manufacturinglntellect.

5 "Hunter S. Thompson interview on "The Rum Diary".

${ }^{6}$ Morrison, Andrew. "PICTURES: The Letter That Helped Hunter S. Thompson's “The Rum Diary" Get Made." SCOUT. August 27, 2011, https://scoutmagazine.ca/2011/08/27/picturesthe-letter-that-helped-hunter-s-thompsons-the-rum-diary-getmade/.

7 "Hunter S. Thompson: Back Story of The Rum Diary".

8 "Hunter S. Thompson interview on "The Rum Diary".

9 "Johnny Depp: Hunter's still with me." Independent.ie. Publication date November 10, 2011, https://www.independent. ie/entertainment/movies/johnny-depp-hunters-still-withme-26791095.html.

\section{Bibliography}

McNair, Brian. 2010. Journalists in Film, Edinburgh University Press.

Thompson, Hunter S. 1972. Fear and Loathing in Las Vegas, Harper Perennial.

Thompson, Hunter S. 1998. The Rum Diary, Bloomsbury. Thompson, Hunter S. 2009. The Gonzo Papers Anthology, Picador

Weingarten, Marc. 2006. The Gang That Wouldn't Write Straight, Crown Publishers.

Wolfe, Tom. 1975. The New Journalism, Picador.

Underwood, Doug. 2008. Journalism and the Novel, Cambridge University Press.

Alexander, Robert and Isager, Christine (editors). 2018. Fear and Loathing Worldwide: Gonzo Journalism Beyond Hunter S. Thompson, Bloomsbury Publishin Inc. 


\section{Filmography}

Almost Famous, 2000. De Cameron Crowe. Estados Unidos da América: Sony Pictures Releasing. Blu-Ray American Psycho, 2000. Estados Unidos da América: Columbia Pictures. Blu-Ray

Blow, 2001. Estados Unidos da América: New Line Cinema. Blu-Ray

Brazil. 1985. Estados Unidos da América \& Reino Unido: 20th Century Fox. Blu-Ray

Breakfast with Hunter, 2003. Estados Unidos da América: CineVegas. DVD

Buy the Ticket, Take the Ride: Hunter S. Thompson on Film, 2006. Estados Unidos da América: StarZ. Blu-Ray Easy Rider. 1969. Estados Unidos da América: Columbia Pictures. Blu-Ray Fear and Loathing in Las Vegas. 1998. De Terry Gilliam. Estados Unidos da América: Universal Pictures. Blu-Ray Fight Club. 1999. Estados Unidos da América: 20th Century Fox. Blu-Ray

Gonzo: The Life and Work of Dr. Hunter S. Thompson, 2008. Reino Unido: Magnolia Home Ent. DVD

Hangover, 2009. Estados Unidos da América: Warner Bros. Pictures. Blu-Ray

Leaving Las Vegas. 1995. Estados Unidos da América: MGM/UA Distribution Co. Blu-Ray

Sleepy Hollow. 1999. Estados Unidos da América: Paramount Pictures. Blu-Ray

The Imaginarium of Doctor Parnasssus, 2009. Canadá, França \& Reino Unido: Lionsgate. Blu-Ray

The Rum Diary. 2011. De Bruce Robinson. Estados Unidos da América: Fox. Blu-Ray

Trainspotting. 1996. Reino Unido: PolyGram Filmed

Entertainment. Blu-Ray

Requiem for a Dream, 2000. Estados Unidos da América: Artisan Entertainment. Blu-Ray

Where the Buffalo Roam. 1980. Estados Unidos da América: Universal Pictures. DVD

\section{Webgraphy}

"Hunter S. Thompson: Back Story of The Rum Diary", YouTube video, 45:54, "ritziszen," March 29, 2015 , https://www.youtube.com/watch?v=Ny9-ENnOIFk\&ab_ channel=ritziszen.

"Hunter S. Thompson interview on "The Rum Diary" (1998)", YouTube video, 22:52, "Manufacturing Intellect," July 28, 2016, https://www.youtube.com/watch?v=LKJbua ItOo\&ab_channel=Manufacturinglntellect.

"Johnny Depp: Hunter's still with me." Independent. ie. Publication date November 10, 2011, https://www. independent.ie/entertainment/movies/johnny-depphunters-still-with-me-26791095.html.

Martin, Daniel. "Johnny Depp remembers unearthing 'The Rum Diary' - video." NME. Publication date November 10, 2011, https://www.nme.com/news/film/johnny-deppremembers-unearthing-the-rum-diary-vid-878610.

Morrison, Andrew. "PICTURES: The Letter That Helped Hunter S. Thompson's "The Rum Diary” Get Made." SCOUT. August 27, 2011, https://scoutmagazine. ca/2011/08/27/pictures-the-letter-that-helped-hunter-sthompsons-the-rum-diary-get-made/. 